\title{
Fertility transitions in developing countries: Progress or stagnation?
}

John Bongaarts

Population Council

Follow this and additional works at: https://knowledgecommons.popcouncil.org/departments_sbsr-pgy

Part of the Demography, Population, and Ecology Commons, Family, Life Course, and Society Commons, and the International Public Health Commons How does access to this work benefit you? Let us know!

\section{Recommended Citation}

Bongaarts, John. 2008. "Fertility transitions in developing countries: Progress or stagnation?" Poverty, Gender, and Youth Working Paper no. 7. New York: Population Council. Version of record: https://doi.org/ 10.1111/j.1728-4465.2008.00157.x 


\section{POVERTY, GENDER, AND YOUTH}

Fertility Transitions in Developing Countries:

Progress or Stagnation?

John Bongaarts

WORKING PAPER NO. $7 \quad 2008$

$\mathcal{Q}$ Population Council 


\section{(1) Population Council}

One Dag Hammarskjold Plaza

New York, New York 10017 USA

www.popcouncil.org

pubinfo@popcouncil.org

For information on Poverty, Gender, and Youth working papers, see www.popcouncil.org/publications/wp/index.html

This material may not be reproduced without written permission from the author.

ISSN: $1554-8538$

(C) 2008 The Population Council, Inc. 


\title{
Fertility Transitions in Developing Countries: Progress or Stagnation?
}

\author{
John Bongaarts
}

An earlier version of this paper was presented at the session on "Fertility declines: Rapid, slow, stalled" at the Annual Meeting of the Population Association of America, New York, 28-31 March 2007. John Bongaarts is Vice President and Distinguished Scholar, Population Council, New York.

The author gratefully acknowledges the financial support for this research provided by the William and Flora Hewlett and Packard Foundations. 


\begin{abstract}
Over the past quarter century fertility has declined rapidly in many developing countries. Projections typically assume that this trend will continue until the replacement level is reached. However, recent evidence suggests that ongoing fertility declines may have slowed or stalled in a number of countries in transition. This study examines the pace of fertility change in developing countries that have multiple DHS surveys to determine whether ongoing transitions are decelerating or stalling. The main findings are that in sub-Saharan African countries, the average pace of decline in fertility is lower around 2000 than in the mid-1990s, and more than half the countries in transition in this region have stalled.
\end{abstract}


In recent decades fertility has declined at a rapid pace in a majority of developing countries. Overall, the total fertility rate of the developing world dropped from 6.0 births per woman in the late 1960s to 2.9 in 2000-2005 (United Nations 2007). Declines have been most rapid in Asia, North Africa, and Latin America, regions where social and economic development has also been relatively rapid. Sub-Saharan Africa also experienced significant declines despite its lagging development. On average, these changes occurred more rapidly than demographers had expected earlier. This is evident from the fertility projections made in the 1970s and 1980s, which were generally higher than the subsequent trends (National Research Council 2000). The most recent projections made by the United Nations (2007) assume that the fertility levels of countries that are in transition will continue their decline until fertility drops slightly below the replacement level.

However, fertility in the developing world declined less rapidly in the 1990s than in earlier decades, and a few countries (e.g., Bangladesh and Egypt) experienced fertility stalls or near-stalls in mid-transition (United Nations 2002). The possibility of a pause during an ongoing fertility transition was first raised in the mid-1980s by Gendell (1985), but the issue was given little attention until recently because in the past stalls have been relatively rare. Interest in the topic is now rising as new survey data in additional countries emerge on stalls in fertility and contraceptive prevalence during the 1990s (Bongaarts 2006; Eltigani 2003; Ross et al. 2004; Shapiro and Gebreselassie 2007; United Nations 2002; Westoff and Cross 2006).

The main objective of this study is to analyze recent trends in the pace of the fertility transitions in developing countries since 1990 to determine whether these transitions are decelerating and how widespread stalling or near-stalling has become around 2000. After a description of the data sources, a regional overview of levels and trends in fertility is provided using estimates from DHS surveys. This is followed by a more detailed assessment of country-level trends. Country estimates of the pace of fertility decline are examined separately for a set of 29 countries with three DHS surveys (which permits analysis of changes in the pace over time) and for a larger set of 40 countries with only two surveys to assess the prevalence of stalling fertility.

\section{DATA}

This analysis relies on fertility estimates from countries with multiple DHS surveys (excluding ex-Soviet republics). For 40 countries at least two such surveys are available since the early 1990s:

- Sub-Saharan Africa: Benin, Burkina Faso, ${ }^{*}$ Cameroon, * Chad, Côte d'Ivoire, ${ }^{*}$ Ethiopia, Ghana,* Guinea, ${ }^{*}$ Kenya, ${ }^{*}$ Madagascar,* Malawi, ${ }^{*}$ Mali, ${ }^{*}$ Mozambique, Namibia, Niger, ${ }^{*}$ Nigeria, Rwanda, ${ }^{*}$ Senegal, ${ }^{*}$ Tanzania,* Uganda, ${ }^{*}$ Zambia, ${ }^{*}$ Zimbabwe.*

- Latin America: Bolivia, ${ }^{*}$ Colombia, ${ }^{*}$ Dominican Republic,* Guatemala,* Haiti, ${ }^{*}$ Nicaragua, Peru.* 
- Asia/North Africa: Bangladesh,* Egypt,* India, Indonesia,* Jordan,* Morocco, ${ }^{*}$ Nepal,* Philippines, ${ }^{*}$ Turkey, Vietnam, Yemen.

The dates of the surveys vary, with the latest survey conducted around 2003 and the previous one around 1997, yielding an average interval of 5.8 years between surveys.

In a subgroup of 29 countries a third survey was available, and the years of the three successive surveys in this subgroup averaged 1992, 1998, and 2004. These countries are indicated with an asterisk $\left(^{*}\right)$ in the above list of country names. The abbreviations DHS0, DHS-1, and DHS-2 are used to refer, respectively, to the last, next to last, and second to last DHS surveys. The availability of three surveys permits the examination of trends during two successive periods: the first period from ca. 1992 to ca. 1998 (between DHS-2 and DHS-1) and the second period from ca. 1998 to ca. 2004 (between DHS-1 and DHS0).

DHS surveys use standardized procedures and questionnaires for collecting demographic and health data; therefore, estimates of measures from different surveys are highly comparable. Nevertheless, Eritrea is deliberately excluded here, because the Eritrea 1999 survey was conducted shortly after a war with Ethiopia, and the fertility rate that was derived from reported births in the three years before this survey was depressed due to the separation of spouses during this conflict (Blanc 2004). In addition, the 1999 surveys in Nigeria and the Dominican Republic are not used. The first country report for the 1999 survey in Nigeria presents persuasive evidence of substantial underreporting of events, resulting in the underestimation of levels of fertility and child mortality (National Population Commission, Nigeria 2000). The 1999 survey in the Dominican Republic had a much smaller sample size than is typical for DHS, resulting in unusually large sampling errors. Fortunately, trends in reproductive behavior in Nigeria and the Dominican Republic are available from earlier and later DHS surveys conducted in these two countries.

Estimates of fertility as measured by the total fertility rate (TFR) in the three years before the survey are taken from DHS first country reports (http://www.measuredhs.com/). The main indicator used below is the pace of fertility decline, defined as the absolute decline per year in the TFR between two successive observations. Fertility declined over time in most countries and inter-survey periods, and the corresponding pace is therefore usually positive. Unless otherwise noted, the determination of statistical significance of results presented below relies on one-tailed t-tests.

\section{Aggregate Trends in Fertility}

Figure 1 plots regional trends in the (unweighted) average total fertility rate based on data for the 29 countries with three surveys in sub-Saharan Africa $(\mathrm{N}=16), \mathrm{Asia} / \mathrm{North}$ Africa $(\mathrm{N}=7)$, and Latin America $(\mathrm{N}=6)$. For each set of countries three observations are plotted, giving estimates from successive surveys conducted ca. 1992, ca. 1998, and ca. 2004 (DHS-2, DHS-1, and DHS0). (The distances between years for successive surveys plotted in Figure 1 are proportional to the average time elapsed between the surveys.) Average fertility is higher in sub-Saharan African countries than in Asian/North African and Latin American countries throughout the observed period. Fertility declines are 
evident in all three regions, both in the most recent period (i.e., between DHS-1 and DHS0) and in the earlier period (i.e., between DHS-2 and DHS-1). In Asia/North Africa and in Latin America the downward trend is quite steady throughout the two periods, but in sub-Saharan Africa the decline is slower in the later period compared to the earlier one. This finding is surprising because fertility declines tend to be most rapid in the early phases of the transition and to slow down after countries have reached mid-transition (National Research Council 2000).

These results are confirmed in Figure 2, which plots the (unweighted) average pace of decline in the TFR for two successive time periods for DHS countries. For each regional set of countries the first estimate is the pace during the interval between DHS-2 and DHS- 1 and the second estimate is for the period between DHS-1 and DHS0. In the first period the average pace of the TFR decline (in births per woman per year) varied little from 0.07 in sub-Saharan Africa and Asia/North Africa to 0.08 in Latin America. For reference, Figure 2 plots a dashed horizontal line at a value of 0.09 births per woman, which equals the average pace of decline in all developing countries (without China) between 1965 and 1990 (United Nations 2007). DHS countries in all regions are slightly (but not significantly) below this past aggregate pace. The results for the earlier period are therefore unsurprising and consistent with the pace of fertility decline in recent decades in the developing world overall (excluding China).

In contrast, in the more recent inter-survey interval the average pace of fertility decline decelerated significantly in sub-Saharan Africa, dropping from 0.07 births per woman per year in the earlier period to 0.02 in the later period $(p<0.05)$. The change in pace in Latin America and in Asia/North Africa is much smaller and not statistically significant. The average pace in the more recent period in Latin America and sub-Saharan Africa is lower than the average experienced between 1965 and 1990 in the developing world (excluding China), but the difference is significant only for sub-Saharan Africa.

\section{COUNTRY-LEVEL TRENDS IN FERTILITY}

The averages presented in the preceding section conceal wide variations in the levels and trends of fertility between countries. The analysis now turns to country-level data and in particular to the country variation in the pace of fertility decline. This section focuses on the set of 29 countries for which three successive surveys are available, thus allowing a comparison of the pace between the first two surveys with the pace between the two most recent surveys. This comparison can therefore shed light on the question of whether fertility transitions are decelerating.

Table 1 presents the TFR for three points in time and pace estimates for the corresponding two successive intervals for countries with three surveys. In the first interval one country (Niger) had a negative pace, which indicates a rise in the TFR, while in the second interval TFR increases occurred in six countries (Cameroon, Guinea, Kenya, Mali, Rwanda and Tanzania), all in sub-Saharan Africa. It should be emphasized that small changes in fertility are often not statistically significant. This issue will be examined further below. 
Figure 3 plots the two successive pace estimates for TFR for all 29 countries with three surveys. The vertical axis plots the pace during the interval between the second to last and the next to last surveys, and the horizontal axis plots the pace for the period between the two most recent surveys. The solid line is the 45-degree diagonal representing observations for which the pace in the last interval equals the pace in the next to last interval. Countries located below this diagonal are experiencing a deceleration in the pace and countries located above the diagonal are experiencing an acceleration. The dashed line represents the best-fitting line for the observations using an OLS regression.

This figure leads to two main findings. First, the relationship between the pace during the last and the next to last survey interval is not statistically significant $(\mathrm{p}>0.05){ }^{1}$ This relationship either does not exist or is too weak to detect in the available data sets, which contain inevitable measurement errors. Second, the number of countries below the diagonal exceeds the number of countries above the diagonal (17 vs. 12), indicating that deceleration is more prevalent than acceleration.

To determine whether a change in the pace of a country's fertility decline is statistically significant, it is necessary to take into account the sampling errors in estimates. The DHS provides such estimates for the TFR. ${ }^{2}$ A statistically significant deceleration in the pace of TFR decline $(p<0.05)$ occurred in four countries: Cameroon, Ghana, Kenya, and Peru. The presence or absence of a significant deceleration provides no information about the pace itself, nor does it indicate whether a fertility decline is or is not different from zero. As shown next, a country can be stalling even though there is no significant deceleration in the pace.

\section{STALLING FERTILITY}

The preceding analysis of changes in the pace of the TFR indicators was limited to the 29 countries with three DHS surveys. An analysis of the pace for one survey interval can be undertaken for a larger set of 40 countries with two successive surveys; for these countries the issue of stalling fertility will be examined.

Table 2 lists the 40 countries with at least two DHS surveys. This set is divided into two groups depending on whether or not a statistically significant decline in fertility occurred in the most recent inter-survey period $(\mathrm{p}<0.05)$. Among these 40 countries 17 had no significant fertility decline. Notably, two thirds $(15 / 22)$ of the sub-Saharan countries show no significant decline, which is a much larger proportion than among Asian/North African and Latin American countries. Significant fertility declines occurred in all but one Asian/North African country (Turkey) and in all but one Latin American country (Guatemala).

The absence of fertility decline is often observed in pre- and post-transitional countries, but it has been a rare occurrence in countries that are in the midst of a transition. A period of no decline in countries in transition is usually referred to as a stall in fertility. A stall implies that an ongoing fertility transition is interrupted by a period of no significant change in fertility before the country reaches the end of the transition. 
To identify the stallers among the 17 countries with no significant fertility decline in Table 2, it is necessary to eliminate pre- and post-transitional countries in which the absence of a decline is not a stall. Countries are generally considered post-transitional when their fertility reaches the replacement level or below. Only one country falls in this category: Vietnam, which had a TFR of 1.9 births per woman at the last survey. The identification of pre-transitional countries is less straightforward. Historical studies often used a fertility decline of 10 percent from pre-transitional levels as an indication of the onset of the transition. This approach cannot be used here because historical data are lacking and the level of pre-transitional fertility cannot be determined accurately. Instead, it is assumed here that a country is pre-transitional if contraceptive prevalence among married women is 10 percent or less. ${ }^{3}$ By this criterion, three countries are pretransitional at the time of the last survey: Chad, Guinea, and Mali. Pre- and posttransitional countries are indicated in parentheses in Table 2.

After excluding the pre- and post-transitional countries, 36 of the 40 countries remain - these are considered to be in transition. Among these transitional countries 14 (i.e., 39 percent) are in a stall, that is, they did not experience a significant fertility decline between the two most recent surveys. More than half the sub-Saharan countries in transition are in a stall (12/19). In accordance with the definition of a stall used here, a few transitional countries with very small TFR declines (less than about 0.25 births per woman) are considered to have stalled because these declines are too small to be statistically significant.

This examination of stalling of the fertility decline was repeated for the earlier interval between DHS-2 and DHS-1. During this period 9 of 25 transitional countries had no significant fertility decline: Bangladesh, Burkina Faso, Dominican Republic, Egypt, Haiti, Indonesia, Madagascar, Senegal, and Tanzania. It is noteworthy that all but one of the countries with a stall in the earlier period experienced a significant TFR decline in the next period (Tanzania is the exception). But the pace of fertility decline in the intersurvey period following a stall is modest, with an average of 0.07 births per woman per year for these 9 countries. This is below the average pace of 0.09 for the developing world (excluding China) between 1965 and 1990. These findings suggest that stalls tend to be temporary, and that after a stall the pace of fertility decline remains relatively low. Nevertheless, the number of countries for which a survey is available after a stall is too small to allow for more definitive conclusions.

\section{CONCLUSION}

Nearly all developing countries had high fertility levels in the 1950s. Since then, most of these countries have experienced substantial declines and a growing number have reached replacement fertility. The record of fertility trends in the developing world suggests that once a fertility decline is underway it often continues without significant interruption until the replacement level of around two births per woman is reached. Stalls in mid-transition before the 1990s were rare (e.g., in Argentina, Chile, and Uruguay). 
This study examined trends in fertility after 1990 using data from DHS surveys. The main conclusion is that the average pace of fertility decline slowed significantly in sub-Saharan African countries from the first (ca. 1992 to ca. 1998) to the second (ca. 1998 to ca. 2004) interval between surveys. Two thirds of sub-Saharan countries experienced no significant decline between the two most recent surveys; even among countries in transition, more than half are in a stall. In contrast, only one Asian/North African country and one Latin American country had stalled.

The causes of the slowing pace of fertility change in sub-Saharan Africa were not examined here, but two factors may have played a role. First, according to conventional theory, socioeconomic development is a key driver of fertility decline (Bulatao and Lee 1983; Caldwell 1982; Easterlin 1975; Notestein 1953). During the 1990s much of the world experienced substantial economic growth, but GDP per capita in sub-Saharan Africa actually declined (World Bank 2005). In addition, life expectancy declined in subSaharan Africa owing to a rapidly spreading AIDS epidemic, while the rest of the world enjoyed rapid improvements in longevity (United Nations 2007). Poorly performing economies and rising mortality are plausible contributing factor to the stalling of fertility in many sub-Saharan countries. Second, the fertility stalls may be attributable in part to the lower priority assigned to family planning programs in recent years (Blanc and Tsui 2005; Cleland et al. 2006).

The unexpected slow pace of fertility decline around 2000 in sub-Saharan Africa has implications for future demographic trends, because minor variations in fertility trends have large effects on the future size and age structure of populations (Casterline 2001). For example, according to the medium variant of the United Nations (2007), the population of sub-Saharan Africa is expected to more than double in size from 769 million in 2005 to 1.76 billion in 2050 (this projection takes into account the large impact of the AIDS epidemic). The UN's high variant projection estimates a population of 2.02 billion in 2050 because it assumes a slightly slower pace of fertility decline than the medium variant (reaching a TFR of 3.0 instead of 2.5 births per woman in 2050). If the recent slow pace of fertility transition persists, it is conceivable that sub-Saharan Africa's population size could approach the high variant. This trend will likely have adverse effects on the region's prospects for social and economic development, food security, and the sustainability of natural resources (Alexandratos 2005; Demeny and McNicoll 2006). 


\section{NOTES}

1 Two-tailed t-test.

2 The standard error for the TFR is provided in an appendix to most DHS first country reports. For a few countries this error was not available and an estimate was obtained from a regression equation. In this regression the log of the relative error (LRE) was the dependent variable, and the square root of the number of respondents $(\mathrm{N})$ and the TFR were the independent variables: $\mathrm{LRE}=-0.014 * \mathrm{~N}-$ $0.10 *$ TFR-2.14 $\left(\mathrm{R}^{2}=0.55\right)$.

3 The threshold of 10 percent for overall contraceptive prevalence is used because on average it corresponds to a fertility decline of about 10 percent according to regressions by Ross et al. (2005) and United Nations (2003).

\section{REFERENCES}

Alexandratos, Nikos. 2005. "Countries with rapid population growth and resource constraints: Issues of food, agriculture, and development," Population and Development Review 31(2): 237-258.

Blanc, Ann K. 2004. "The role of conflict in the rapid fertility decline in Eritrea and prospects for the future," Studies in Family Planning 35(4): 236-245.

Blanc, Ann K. and Amy O. Tsui. 2005. "The dilemma of past success: Insiders' views on the future of the international family planning movement," Studies in Family Planning 36(4): 263-276.

Bongaarts, John. 2006. "The causes of stalling fertility transitions," Studies in Family Planning 37(1): 1-16.

Bulatao, Rodolfo A. and Ronald D. Lee (eds.). 1983. Determinants of Fertility in Developing Countries. 2 Volumes. New York: Academic Press.

Caldwell, John C. 1982. Theory of Fertility Decline. New York: Academic Press.

Casterline, John B. 2001. "The pace of fertility transition: National patterns in the second half of the twentieth century," in Global Fertility Transition, (eds.) Rodolfo A. Bulatao and John B. Casterline. Population and Development Review, Supplement to Vol. 27. New York: Population Council, pp. 17-52. 
Cleland, John, Stan Bernstein, Alex Ezeh, Anibal Faundes, Anna Glasier, and Jolene Innis. 2006. "Family planning: The unfinished agenda," Lancet 368 (9549): 18101827.

Demeny, Paul and Geoffrey McNicoll. 2006. "The political demography of the world system, 2000-2050," in The Political Economy of Global Population Change, 1950-2050, Demeny and McNicoll (eds.), Supplement to Population and Development Review. New York: Population Council, pp. 254-287.

Easterlin, Richard A. 1975. "An economic framework for fertility analysis," Studies in Family Planning 6(3): 54-63.

Eltigani Eltigani. 2003. "Stalled fertility decline in Egypt, why?" Population and Environment 25(1): 41-59.

Gendell, Murray. 1985. "Stalls in the fertility decline in Costa Rica, Korea, and Sri Lanka," World Bank Staff Working Paper No. 693. Washington, DC: World Bank.

National Population Commission [Nigeria]. 2000. Nigeria Demographic and Health Survey 1999. Calverton, MD: National Population Commission and ORC/Macro.

National Research Council. 2000. Beyond Six Billion: Forecasting the World's Population. Panel on Population Projections, John Bongaarts and Rodolfo Bulatao, eds. Committee on Population, Commission on Behavioral and Social Sciences and Education. Washington, DC: National Academy Press.

Notestein, Frank W. 1953. "Economic problems of population change," in Proceedings of the Eighth International Conference of Agricultural Economics. London: Oxford University Press. pp. 13-31.

Ross, John, Edward Abel, and Katherine Abel. 2004. "Plateaus during the rise of contraceptive prevalence," International Family Planning Perspectives 30(1): 3944.

Ross, John, John Stover, and Demi Adelaja. 2005. Profiles for Family Planning and Reproductive Health Programs: 116 Countries. $2^{\text {nd }}$ edition. Glastonbury, CT: The Futures Group.

Shapiro, David and Tesfayi Gebreselassie. 2007. "Fertility transition in sub-Saharan Africa: Falling and stalling," paper presented at the session on "Fertility declines: Rapid, slow, stalled" at the Annual Meeting of the Population Association of America, New York, 28-31 March. 
United Nations. 2002. "Fertility levels and trends in countries with intermediate levels of fertility," in Completing the Fertility Transition, Report of the Expert Group Meeting on Completing the Fertility Transition, Department of Economic and Social Affairs, Population Division. ESA/P/WP.172/Rev.1. New York: United Nations. <http://www.un.org/esa/population/publications/completingfertility/ completingfertility.htm>.

United Nations. 2003. Levels and Trends of Contraceptive Use as Assessed in 2002. Department of Economic and Social Affairs New York: United Nations. ST/ESA/SER.A/190

United Nations 2007. World Population Prospects: The 2006 Revision. Department of Economic and Social Affairs, Population Division. New York: United Nations.

Westoff, Charles and Anne Cross. 2006. "The stall in the fertility transition in Kenya," DHS Analytic Studies 9. Calverton, MD: ORC Macro.

World Bank. 2005. Economic Growth in the 1990s: Learning from a Decade of Reform. Washington, DC: World Bank. 
Table 1: Total fertility rate and pace of fertility decline for 29 countries with three DHS surveys

\begin{tabular}{|c|c|c|c|c|c|}
\hline \multirow[b]{2}{*}{ Country } & \multicolumn{3}{|c|}{ Total fertility rate } & \multicolumn{2}{|c|}{ Pace of decline } \\
\hline & $\begin{array}{c}\text { DHS-2 } \\
\text { ca. } 1992 \\
\end{array}$ & $\begin{array}{l}\text { DHS-1 } \\
\text { ca. } 1998\end{array}$ & $\begin{array}{c}\text { DHS0 } \\
\text { ca. } 2004\end{array}$ & $\begin{array}{c}\text { DHS-2 to } \\
\text { DHS-1 }\end{array}$ & $\begin{array}{c}\text { DHS-1 to } \\
\text { DHSO }\end{array}$ \\
\hline Burkina Faso & 6.5 & 6.4 & 5.9 & 0.02 & 0.11 \\
\hline Cameroon & 5.8 & 4.8 & 5.0 & 0.14 & -0.03 \\
\hline Côte d'Ivoire & 5.7 & 5.2 & 4.6 & 0.10 & 0.11 \\
\hline Ghana & 5.2 & 4.4 & 4.4 & 0.16 & 0.00 \\
\hline Guinea & 5.7 & 5.5 & 5.7 & 0.03 & -0.03 \\
\hline Kenya & 5.4 & 4.7 & 4.9 & 0.14 & -0.04 \\
\hline Madagascar & 6.1 & 6.0 & 5.2 & 0.02 & 0.12 \\
\hline Malawi & 6.7 & 6.3 & 6.0 & 0.05 & 0.08 \\
\hline Mali & 7.1 & 6.7 & 6.8 & 0.05 & -0.02 \\
\hline Niger & 7.4 & 7.5 & 7.1 & -0.02 & 0.05 \\
\hline Rwanda & 6.2 & 5.8 & 6.1 & 0.05 & -0.06 \\
\hline Senegal & 6.0 & 5.7 & 5.3 & 0.07 & 0.05 \\
\hline Tanzania & 5.8 & 5.6 & 5.7 & 0.07 & -0.02 \\
\hline Uganda & 7.4 & 6.9 & 6.9 & 0.07 & 0.00 \\
\hline Zambia & 6.5 & 6.1 & 5.9 & 0.10 & 0.04 \\
\hline Zimbabwe & 4.3 & 4.0 & 3.8 & 0.06 & 0.03 \\
\hline Egypt & 3.6 & 3.5 & 3.1 & 0.02 & 0.08 \\
\hline Jordan & 5.6 & 4.4 & 3.7 & 0.17 & 0.14 \\
\hline Morocco & 4.6 & 4.0 & 2.5 & 0.12 & 0.13 \\
\hline Bangladesh & 3.3 & 3.3 & 3.0 & 0.00 & 0.07 \\
\hline Indonesia & 2.9 & 2.8 & 2.6 & 0.03 & 0.04 \\
\hline Nepal & 4.6 & 4.1 & 3.1 & 0.10 & 0.20 \\
\hline Philippines & 4.1 & 3.7 & 3.5 & 0.08 & 0.04 \\
\hline Bolivia & 4.8 & 4.2 & 3.8 & 0.15 & 0.08 \\
\hline Colombia & 3.0 & 2.6 & 2.4 & 0.08 & 0.04 \\
\hline Dominican Republic & 3.3 & 3.2 & 3.0 & 0.02 & 0.03 \\
\hline Guatemala & 5.5 & 5.1 & 5.0 & 0.05 & 0.03 \\
\hline Haiti & 4.8 & 4.7 & 4.0 & 0.02 & 0.13 \\
\hline Peru & 3.5 & 2.8 & 2.4 & 0.18 & 0.10 \\
\hline
\end{tabular}

Source: DHS surveys. 
Table 2: Countries by pace of fertility decline between the last two DHS surveys

\begin{tabular}{|c|c|c|c|}
\hline Pace of decline & $\begin{array}{l}\text { Sub-Saharan } \\
\text { Africa }\end{array}$ & $\begin{array}{l}\text { Asia/ } \\
\text { North Africa }\end{array}$ & Latin America \\
\hline $\begin{array}{l}\text { No significant } \\
\text { decline }\end{array}$ & $\begin{array}{l}\text { Cameroon } \\
\text { (Chad) } \\
\text { Côte d'Ivoire } \\
\text { Ethiopia } \\
\text { Ghana } \\
\text { (Guinea) } \\
\text { Kenya } \\
\text { (Mali) } \\
\text { Mozambique } \\
\text { Nigeria } \\
\text { Rwanda } \\
\text { Tanzania } \\
\text { Uganda } \\
\text { Zambia } \\
\text { Zimbabwe }\end{array}$ & Turkey & Guatemala \\
\hline Significant decline* & $\begin{array}{l}\text { Benin } \\
\text { Burkina Faso } \\
\text { Madagascar } \\
\text { Malawi } \\
\text { Namibia } \\
\text { Niger } \\
\text { Senegal }\end{array}$ & $\begin{array}{l}\text { Bangladesh } \\
\text { Egypt } \\
\text { India } \\
\text { Indonesia } \\
\text { Jordan } \\
\text { Morocco } \\
\text { Nepal } \\
\text { Philippines } \\
\text { Yemen } \\
\text { (Vietnam) }\end{array}$ & $\begin{array}{l}\text { Bolivia } \\
\text { Colombia } \\
\text { Dominican Republic } \\
\text { Haiti } \\
\text { Nicaragua } \\
\text { Peru }\end{array}$ \\
\hline
\end{tabular}

Source: DHS surveys.

Parentheses indicate pre- or post-transitional societies (see text).

${ }^{*} \mathrm{p}<0.05$, one-tailed t-test. 
Figure 1: Unweighted average of country-specific total fertility rates for three successive DHS surveys

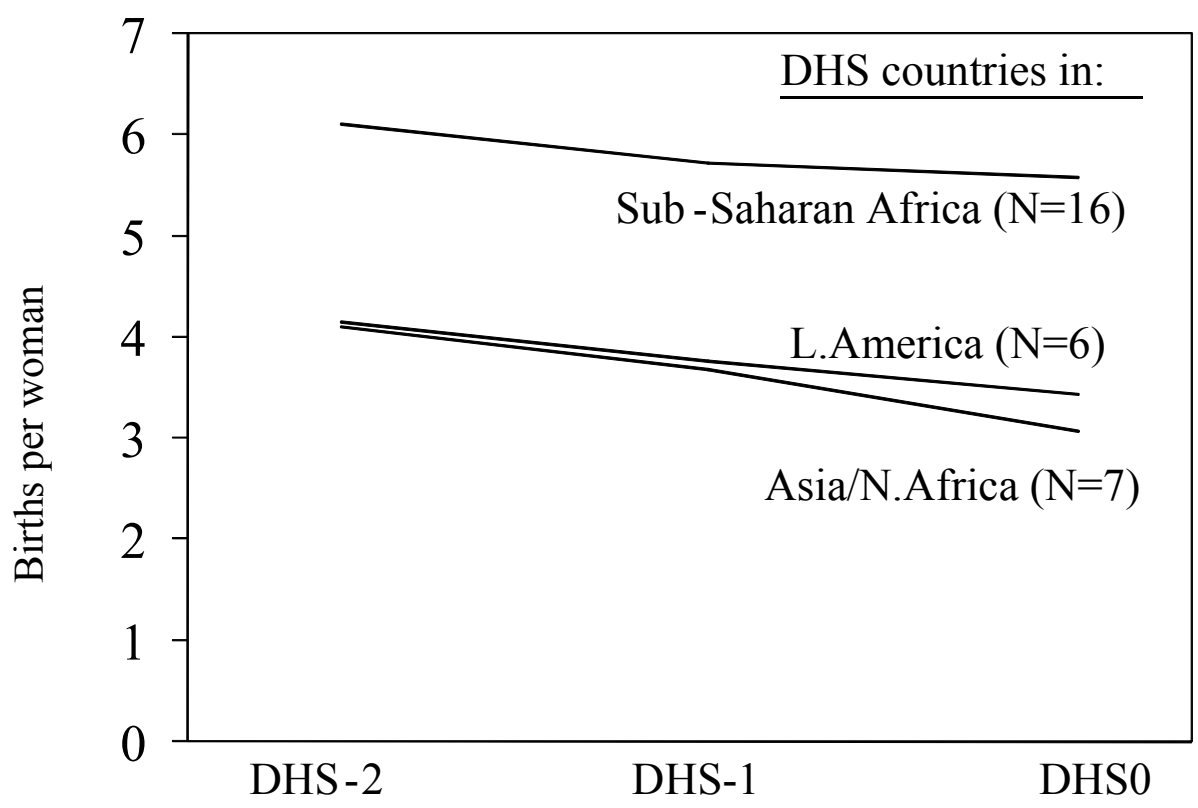

Figure 2: Unweighted average pace of TFR decline for period between DHS-2 and DHS-1 and period between DHS-1 and DHS0

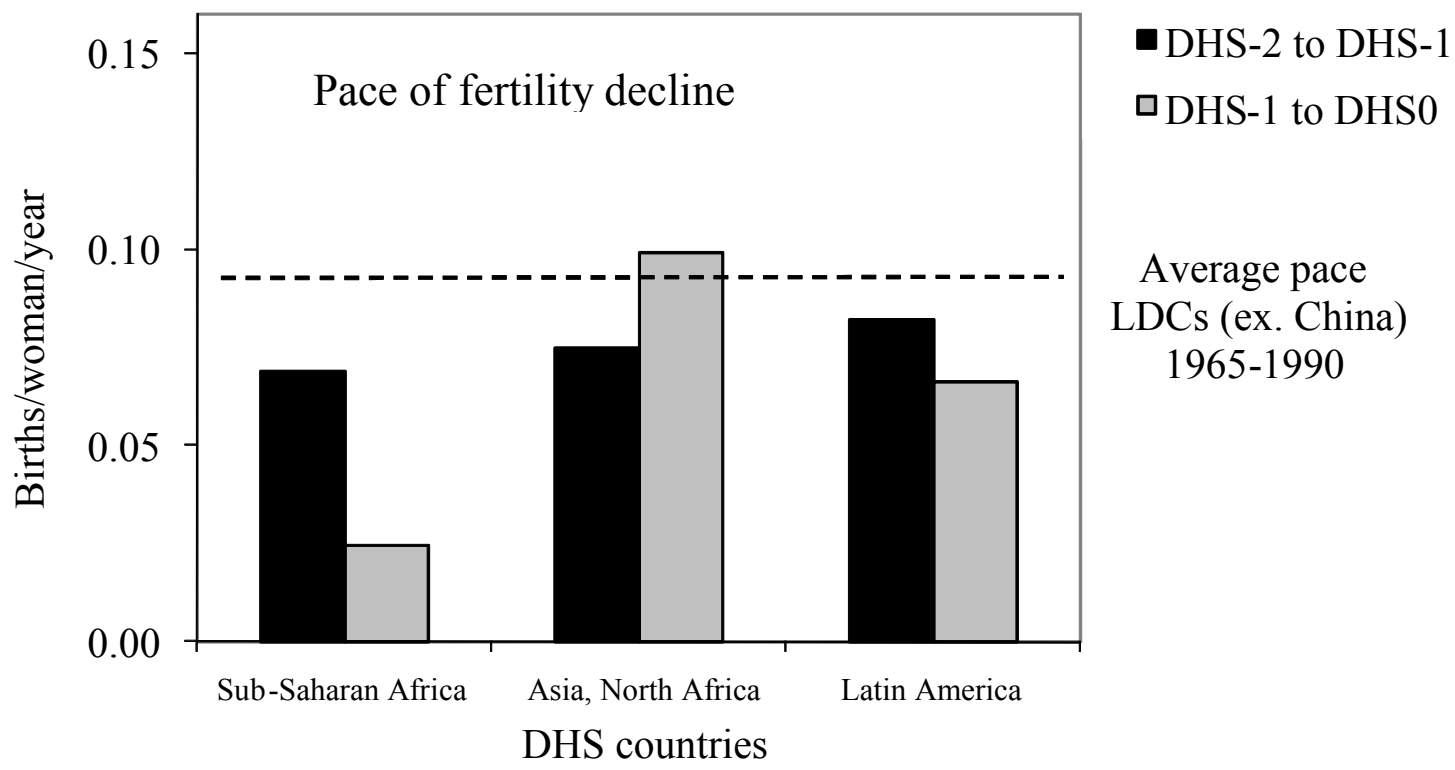


Figure 3: Relationship between pace of fertility decline from DHS-2 to DHS- 1 and pace from DHS-1 to DHS-0 in 29 DHS countries






\section{Poverty, Gender, and Youth Working Papers}

If still in print, single copies of up to three working papers from 1989 through 2003 are available free of charge.

Beginning with the 2004 issues, working papers are no longer available in print format. Instead they are distributed electronically. As each new paper is completed, subscribers are notified by e-mail and a link to the paper is provided.

To subscribe to the Poverty, Gender, and Youth working paper e-mail notification list, or to obtain back issues from 1989 to 2003, please send your request to pgywp@popcouncil.org.

PDFs of recent issues are available at www.popcouncil.org/publications/wp/index.html

2008

$7 \quad$ John Bongaarts, "Fertility transitions in developing countries: Progress or stagnation?"

2007

6 Cynthia B. Lloyd, "The role of schools in promoting sexual and reproductive health among adolescents in developing countries."

5 Ann Biddlecom, Richard Gregory, Cynthia B. Lloyd, and Barbara S. Mensch, "Premarital sex and schooling transitions in four subSaharan African countries."

4 Sajeda Amin, John B. Casterline, and Laura Spess, "Poverty and fertility: Evidence and agenda."

3 Bussarawan Teerawichitchainan and James F. Phillips, "Ethnic differentials in parental health seeking for childhood illness in Vietnam."

2 Zachary Zimmer, Kim Korinek, John Knodel, and Napaporn Chayovan, "Support by migrants to their elderly parents in rural Cambodia and Thailand: A comparative study."
1 Sharon Ghuman and Cynthia B. Lloyd, "Teacher absence as a factor in gender inequalities in access to primary schooling in rural Pakistan.”

\section{Policy Research Division working papers}

2006

219 Cynthia B. Lloyd and Barbara S. Mensch, "Marriage and childbirth as factors in school exit: An analysis of DHS data from sub-Saharan Africa."

218 Ayaga A. Bawah, James F. Phillips, Martin Adjuik, Maya VaughanSmith, Bruce MacLeod, and Fred N. Binka, "The impact of immunization on the association between poverty and child survival: Evidence from Kassena-Nankana District of northern Ghana."

217 Zachary Zimmer, "Poverty, wealth inequality, and health among older adults in rural Cambodia."

216 John Bongaarts, "Late marriage and the HIV epidemic in sub-Saharan Africa."

215 John Bongaarts, "How long will we live?" 
214 Zachary Zimmer, Toshiko Kaneda, and Laura Spess, "Urban versus rural mortality among older adults in China."

213 Paul Demeny and Geoffrey

McNicoll, "The political demography of the world system, 2000-2050."

212 Monica Grant and Kelly Hallman, "Pregnancy-related school dropout and prior school performance in South Africa."

211 Kelly Hallman, Sara Peracca, Jennifer Catino, and Marta Julia Ruiz, "Multiple disadvantages of Mayan females: The effect of gender, ethnicity, poverty, and residence on education in Guatemala."

210 Geoffrey McNicoll, "Policy lessons of the East Asian demographic transition."

209 Cynthia B. Lloyd, Cem Mete, and Monica J. Grant, "The implications of changing educational and family circumstances for children's grade progression in rural Pakistan: 19972004." 